\title{
OPTICAL RESISTANCE AND SPECTRAL PROPERTIES OF ANTI- REFLECTIVE COATINGS DEPOSITED ON LBO CRYSTALS BY ION BEAM SPUTTERING
}

\author{
G. Abromavičius ${ }^{\text {a,b }}$, R. Buzelis a ${ }^{\text {, R. Drazdys }}{ }^{\text {a }}$, K. Juškevičius ${ }^{\text {a }, ~ S . ~ K i c ̌ a s ~ a ~}{ }^{\text {, T. Tolenis }}{ }^{\text {a }}$, \\ J. Mirauskas s ${ }^{c}$, M. Ščiuka ${ }^{c}$, V. Sirutkaitis ${ }^{c}$, and A. Melninkaitis ${ }^{c}$ \\ a State Scientific Research Institute Center for Physical Sciences and Technology, Savanoriu 231, LT-02300 \\ Vilnius, Lithuania \\ E-mail: rbuzelis@ktl.mii.lt \\ b Optida Co Ltd, A. Goštauto 12, LT-01108, Vilnius, Lithuania \\ ${ }^{c}$ Vilnius University Laser Research Center, Sauletekio 10, LT-10223 Vilnius, Lithuania \\ E-mail: andrius.melninkaitis@ff.vu.lt
}

Received 11 October 2011; accepted 1 December 2011

\begin{abstract}
The nonlinear $\mathrm{LBO}\left(\mathrm{LiB}_{3} \mathrm{O}_{5}\right)$ crystal is widely used in many $\mathrm{Nd}: \mathrm{YAG}, \mathrm{Yb}: \mathrm{KGW}$ and $\mathrm{Nd}$ : YLF lasers in order to generate higher optical harmonics. However, the most limiting factor in such applications is the optical resistance of their coated surfaces described by the so-called Laser Induced Damage Threshold (LIDT) parameter. In this work we investigate the "fatigue" (multi-pulse) behaviour of LIDTs in LBO crystals coated with different types of (single AR@355 nm and triple AR@355+532+1064 nm wavelength) anti-reflective coatings while optimising the refractive index designs and selecting appropriate sub-layer materials. All the coatings were produced of different oxide materials $\left(\mathrm{ZrO}_{2}, \mathrm{Al}_{2} \mathrm{O}_{3}, \mathrm{SiO}_{2}\right)$ and $\mathrm{ZrO}_{2}-\mathrm{SiO}_{2}$ mixtures by using the ion beam sputtering (IBS) deposition technique. The optical damage resistance of both fixed and transient refractive index coatings is of special interest. Besides the spectral properties, the resistance to laser irradiation is characterised at the wavelength of $355 \mathrm{~nm}$ with laser pulses of nanosecond duration. The conclusions are drawn about the AR coated LBO with the most successful designs by the means of optical resistance.
\end{abstract}

Keywords: frequency-doubled AR coating, LIDT, LBO, IBS

PACS: 42.79.Wc, 42.79.Nv, 81.15.Cd, 68.60.-p, 68.37.-d

\section{Introduction}

The laser-induced damage of coated nonlinear crystals (in example, LBO or other optical material) is frequently a limiting factor in the high-power laser applications. LBO crystal is an excellent nonlinear material highly transparent in a wide spectral range (from 160 to $3500 \mathrm{~nm}$ ) that is typically used for frequency conversion [1]. On the other hand, LBO is also one of the most resistive materials to laser radiation $[2,3]$. However, it is necessary to deposit antireflection (AR) coatings on the crystal surfaces in order to reduce reflectance losses of fundamental and higher order generated harmonics [4]. It is also known that LIDTs of coated LBO crystal surfaces are strongly dependent on the quality of surface polishing which also affects the adhesion between coating and crystal $[5,6]$ and, furthermore, on the technology and materials of AR coatings. Here, our research is mostly focused on design optimisation and material selection for antireflective coatings with traditional four layer systems of discrete (mixed $\mathrm{ZrO}_{2}$ and $\mathrm{SiO}_{2}, \mathrm{Al}_{2} \mathrm{O}_{3}$, $\mathrm{SiO}_{2}$ ) and gradient (mixed $\mathrm{ZrO}_{2}$ and $\mathrm{SiO}_{2}$ ) refractive index profiles. The main goal of our research is to develop multi-wavelength antireflection coatings (AR@355+532+1064 nm) on LBO that have a high damage threshold at higher repetition rates $(\mathrm{kHz})$ of laser pulse irradiation. More than 30 experimental deposition processes were made 
in total on fused silica (FS) and LBO substrates. Later, the so-called S-on-1 comparative LIDT tests were conducted at $355 \mathrm{~nm}$ wavelength on the vast majority of coatings at two fixed laser pulse repetition rates $(10 \mathrm{~Hz}$ and $6 \mathrm{kHz})$ in order to identify the best performing coatings.

\section{Deposition of experimental coatings and LIDT measurements}

Recent advance in the ion beam sputtering (IBS) technology with zone target materials allows mixing of the oxide materials [7]. Such approach allows producing very complex designs of thin films with tailored optical constants. The zone target of materials to be sputtered consists of two metallic plates which are placed together. Co-sputtering of both materials takes place simultaneously and if the ion beam is sweeping over this joint area, a mixture of materials is formed on the substrate surface. The portion of each coating material in the mixture layer is defined by the position of the zone target relatively to the ion beam. The coating system software is controlling the zone target position and the deposition time of the individual layers. For determining the thickness of each layer in the stack, a broad-band optical monitoring is employed, which is described elsewhere $[8,9]$. Due to the implementation of advanced optical monitoring in the fully automated process control scheme, the production of gradient index coatings is carried out without further interaction with an operator. The following designs of experimental AR coatings were selected for examination:

(a) regular discrete refractive index profile $-\mathrm{LBO} / \mathrm{L}_{\text {buf }} \mathrm{HL}$...HL/air, where $\mathrm{L}$ is $\mathrm{SiO}_{2}$, $\mathrm{L}_{\text {buf }}$ is $31 \mathrm{~nm}$ buffer layer of $\mathrm{SiO}_{2}, \mathrm{H}$ is $\mathrm{ZrO}_{2}$ $\mathrm{SiO}_{2} \operatorname{mix}\left(30 \%\right.$ or $20 \%$ of $\left.\mathrm{ZrO}_{2}\right)$ or pure $\mathrm{Al}_{2} \mathrm{O}_{3}$;

(b) different gradient index profile designs where the highest percentage of $\mathrm{ZrO}_{2}$ in the mixture layers was also $30 \%$ and the lowest was $20 \%$.

Primarily, single antireflective UV coating for $355 \mathrm{~nm}$ with enhanced transmission at $532 \mathrm{~nm}$ and $1064 \mathrm{~nm}$ wavelengths was investigated $\left(\mathrm{AR}_{355}+\mathrm{HT}_{532+1064}\right)$. Since the pure $\mathrm{ZrO}_{2}$ material has increased absorption losses close to the resonance absorption edge (at $355 \mathrm{~nm}$ wavelength), we have used $\mathrm{ZrO}_{2}-\mathrm{SiO}_{2}$ mixtures which allows one to shift that edge towards UV range and reduce absorption losses: the band-gap of the mixture materials is strongly varying with the content of $\mathrm{SiO}_{2}$. Previous investigations showed that by increasing the $\mathrm{SiO}_{2}$ portion in the mixture up to $50 \%$, a blue shift of the absorption edge of approximately $40 \mathrm{~nm}$ was observed [10]. On the other hand, content of $\mathrm{ZrO}_{2}$ in the mixture cannot be too low, because it is necessary to have a sufficient contrast ratio of refractive indices of coating materials to achieve very low residual reflection $<0.1 \%$ of the AR coating. Due to this, our AR coatings were designed by using minimal $\mathrm{ZrO}_{2}$ content of 20-30\% in the mixture. $\mathrm{Al}_{2} \mathrm{O}_{3}$ has the smallest UV absorption among all high refractive index oxide materials and is widely used in UV coatings. Since the $\mathrm{ZrO}_{2}-\mathrm{SiO}_{2}$ mixture materials can reach bandgap and absorption properties similar to those of pure $\mathrm{Al}_{2} \mathrm{O}_{3}$, we also wanted to compare their LIDT performance on LBO crystals. It should also be noted that all AR coatings, despite used materials $\left(\mathrm{Al}_{2} \mathrm{O}_{3}\right.$ or $\mathrm{ZrO}_{2}-\mathrm{SiO}_{2}$ mixtures), were designed using similar reflectance criteria.

Based on primary investigation with single wavelength antireflective coating, we designed an optimised AR coating for frequency-doubled and tripled wavelengths by using (20-30)\% $\mathrm{ZrO}_{2}-\mathrm{SiO}_{2}$ mixtures instead of pure oxides and having low $<(0.1-0.3) \%$ residual reflection. The profiles of refractive indices and reflection spectra of designed coatings are shown in Fig. 1.

The residual reflectance values at wavelengths of 355, 532 and $1064 \mathrm{~nm}$ are given in Table 1.

Automated S-on-1 (1000-on-1) measurements of LIDTs were performed according to ISO 11254-2 norm [11] by using two different laser sources (Baltic HP and NL303G - EKSPLA, Lithuania) generating UV pulses of nanosecond duration. In situ damage detection has been realised by monitoring a change in the character of light scattered from the coating. In case of damage, the scattering signal is increased and irradiation is stopped. Software based on the programming package LabWIEW was used in order to control the measurement procedure: positioning of experimental sample in $X$ and $Y$ directions, attenuation of laser pulse energy, shutter, automation of damage detection and statistical result analysis [12]. The main parameters are presented in Table 2. 


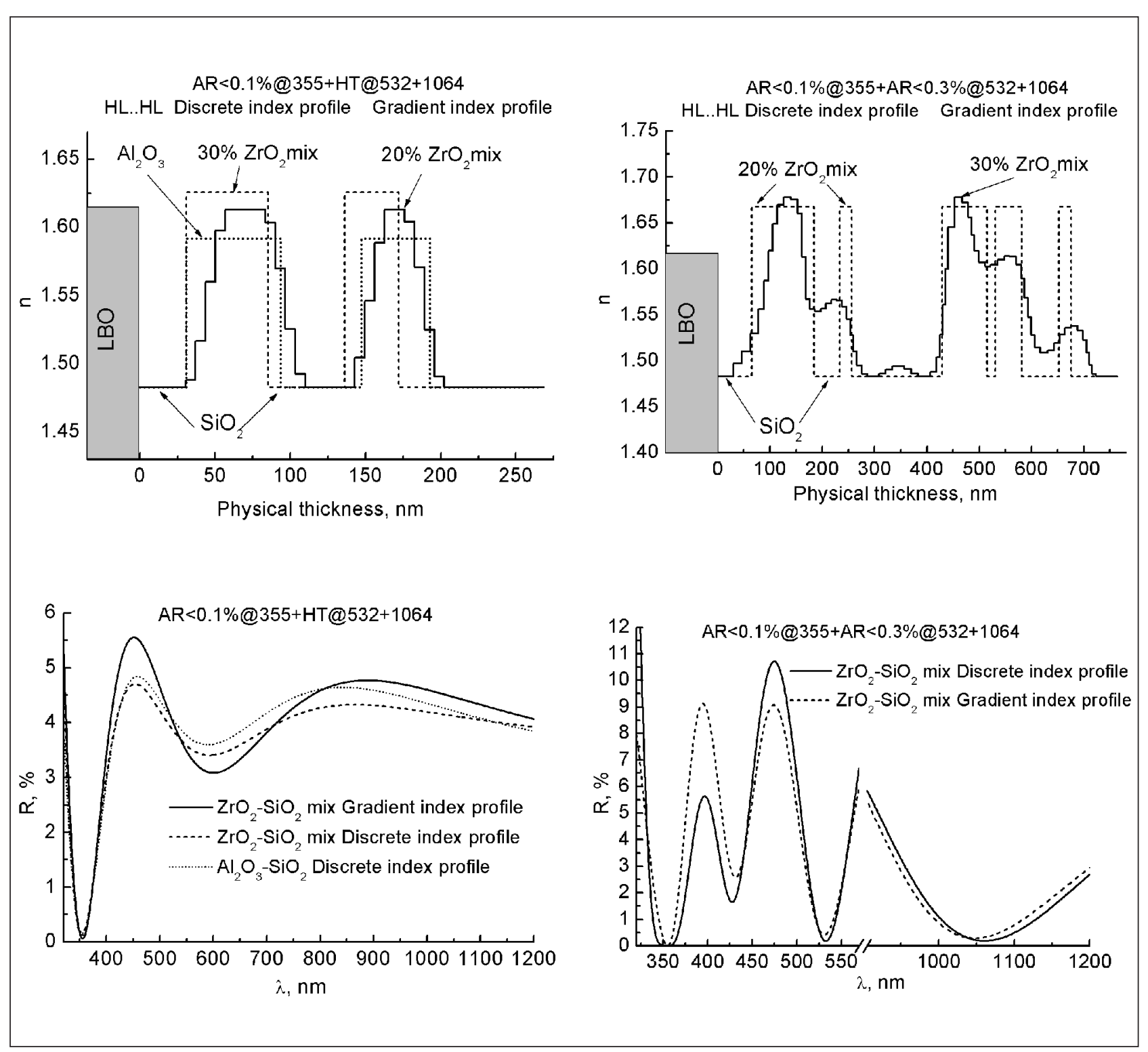

Fig. 1. Calculated refractive index profiles and spectra of $\mathrm{AR}_{355}+\mathrm{HT}_{532+1064}$ (left) and $\mathrm{AR}_{355+532+1064}$ (right) coatings on LBO.

Table 1. Residual reflectance of AR coated LBO sample surface.

\begin{tabular}{|c|c|c|c|}
\hline Coating type & $\mathrm{R}_{355}, \%$ & $\mathrm{R}_{532}, \%$ & $\mathrm{R}_{1064}, \%$ \\
\hline$\left(\mathrm{ZrO}_{2}-\mathrm{SO}_{2}\right.$ mix $)$ Discrete index $\mathrm{AR}_{355}+\mathrm{HT}_{532+1064}$ & 0.11 & 3.8 & 4.0 \\
\hline$\left(\mathrm{Al}_{2} \mathrm{O}_{3} / \mathrm{SiO}_{2}\right) \mathrm{AR}_{355}+\mathrm{HT}_{532+1064}$ & 0.14 & 4.1 & 4.2 \\
\hline$\left(\mathrm{ZrO}_{2}-\mathrm{SO}_{2}\right.$ mix $)$ Gradient index $\mathrm{AR}_{355}+\mathrm{HT}_{532+1064}$ & 0.07 & 4.0 & 4.5 \\
\hline$\left(\mathrm{ZrO}_{2}-\mathrm{SO}_{2}\right.$ mix $)$ Discrete index $\mathrm{AR}_{355+532+1064}$ & 0.06 & 0.1 & 0.2 \\
\hline$\left(\mathrm{ZrO}_{2}-\mathrm{SO}_{2}\right.$ mix $)$ Gradient index $\mathrm{AR}_{355+532+1064}$ & 0.07 & 0.4 & 0.3 \\
\hline
\end{tabular}

Table 2. Parameters of the lasers used for LIDT tests.

\begin{tabular}{c|ccccc|c}
\hline Laser & $\lambda, \mathrm{nm}$ & Pulse rep. rate & $\tau, \mathrm{ns}$ & $\tau$, std, ns & Beam width $\left(1 / \mathrm{e}^{2}\right)$ \\
\hline \multirow{2}{*}{ Baltic HP } & 355 & $10 \mathrm{~Hz}$ & 8.74 & 0.44 & $39 \mu \mathrm{m}$ \\
\cline { 2 - 6 } & 355 & $6 \mathrm{kHz}$ & 7.51 & 0.29 & $37 \mu \mathrm{m}$ \\
\hline \multirow{2}{*}{ NL303G } & 355 & $10 \mathrm{~Hz}$ & 5.09 & 0.33 & $38 \mu \mathrm{m}$ \\
\hline
\end{tabular}




\section{Results and discussion}

The LIDT of the LBO samples is shown in Fig. 2.

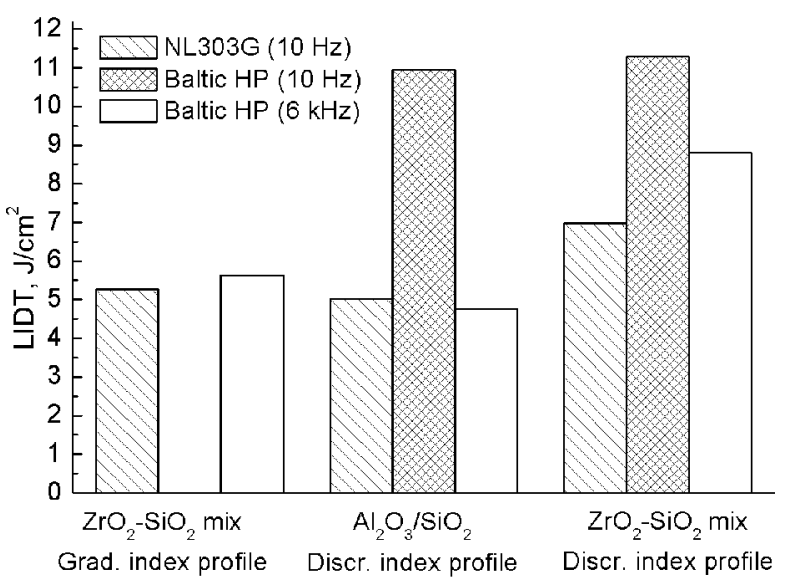

Fig.2.Summary of 1000-on-1 LIDT test results@355 nm (coating on $\mathrm{LBO} \mathrm{AR}{ }_{355}+\mathrm{HT}_{532+1064}$ ).

LIDTs of $\mathrm{ZrO}_{2}-\mathrm{SiO}_{2}$ mixture based AR coatings were higher than those based on $\mathrm{Al}_{2} \mathrm{O}_{3} / \mathrm{SiO}_{2}$ layers. This result can be explained by possible incomplete stoichiometry of $\mathrm{Al}_{2} \mathrm{O}_{3}$ films in the coating and its microstructure inhomogeneity. Annealing of $\mathrm{Al}_{2} \mathrm{O}_{3}$ based coatings at high temperature could improve optical and resistance properties, but the LBO crystals are too sensitive to high temperatures, so annealing procedure was not possible. LIDT results also demonstrate that the optical resistance decreases for shorter and deeper-modulated multimode laser pulses. As it can be seen in Fig. 2, when increasing the same Baltic HP laser pulse repetition rate, the damage threshold is decreasing.

The typical dynamics of the LIDT dependence on the number of pulses (or degradation of resistivity) with different pulse repetition rates is shown in Fig. 3.

The degradation of the tested AR coatings was caused not only by the number of pulses, but also by the pulse repetition rate: the LIDT dynamic dependence on the repetition rate reveals that generation and accumulation of the absorbing defects is faster at higher laser pulse repetition rates. One of the reasons of more rapid decrease of LIDT during exposure to laser pulses of higher repetition rates could be the destruction of metal-oxide bonds within the coatings during UV radiation and their insufficient partial recovery between the pulses. Visual colour changes are observed at an incident beam spot on the coating surface and indicate the formation of absorption centres. However, deeper studies about these phenomena are necessary in order to draw the final conclusions.

The LIDT value for optimised triple antireflective coating $\left(\mathrm{AR}_{355+532+1064}\right)$ using $\mathrm{ZrO}_{2}-\mathrm{SiO}_{2}$ mixtures on $\mathrm{LBO}$ crystals at $10 \mathrm{~Hz}$ pulse repetition rate was $10.8 \mathrm{~J} / \mathrm{cm}^{2}$ for gradient index profile and $8.4 \mathrm{~J} /$ $\mathrm{cm}^{2}$ for discrete index profile coatings. These values are comparable to single antireflective coating with enhanced transmission at $532 \mathrm{~nm}$ and $1064 \mathrm{~nm}$ $\left(\mathrm{AR}_{355}+\mathrm{HT}_{532+1064}\right)$ despite that $\mathrm{AR}_{355+532+1064}$ has more than double physical thickness.

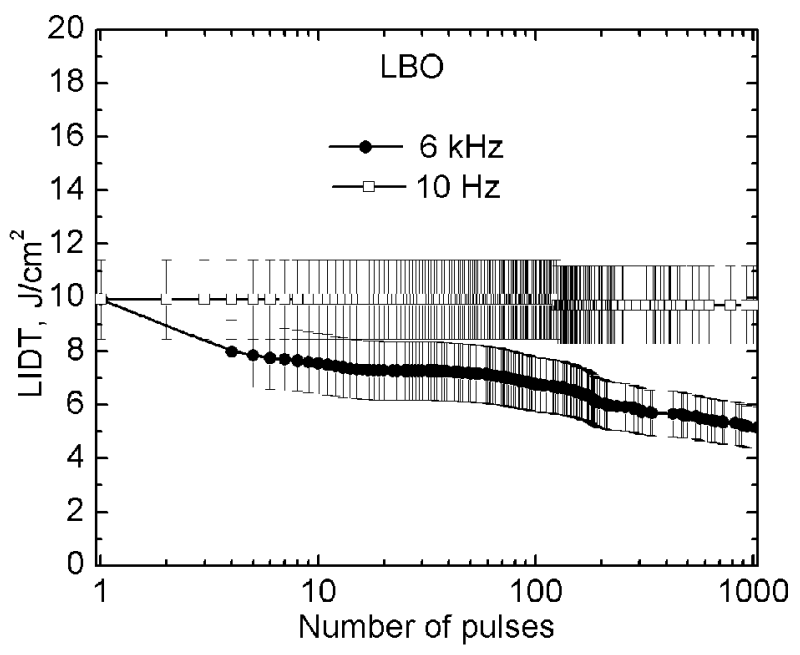

Fig. 3. Typical LIDT curves of coated LBO crystals (coating $\mathrm{AR}_{355}+\mathrm{HT}_{532+1064}$ ).

\section{Conclusions}

We conclude that the mixture approach is suitable for the production of triple AR coatings $\left(\mathrm{AR}_{355+532+1064}\right)$ on $\mathrm{LBO}$ with good antireflective and laser resistance performance at the third harmonic. $\mathrm{ZrO}_{2}-\mathrm{SiO}_{2}$ mixture based gradient index profile $\mathrm{AR}$ coatings on $\mathrm{LBO}$ at $6 \mathrm{kHz}$ repetition rate demonstrated considerably higher LIDT than $\mathrm{Al}_{2} \mathrm{O}_{3} / \mathrm{SiO}_{2}$ based coatings. The influence of the pulse repetition rate has been experimentally observed: the LIDT after 1000 pulses of $355 \mathrm{~nm}$ wavelength irradiation is lower at a higher pulse repetition rate 
in all cases. Therefore, LIDT measurements should be conducted at the repetition rates as close as possible to the real operation conditions of the coated LBO since there is no scaling formula that could describe LIDT behaviour with respect to the repetition rate. Furthermore, a shorter pulse duration causes a lower threshold.

\section{Acknowledgements}

The research leading to these results has been partially supported from project EIGULYS (Grant No. 31V-140) of the Lithuanian Agency for Science, Innovation and Technology.

\section{References}

[1] C. Chen, Y. Wu, A. Jiang, B. Wu, G. You, R. Li, and S. Lin, New nonlinear-optical crystal: LiB3O5, J. Opt. Soc. Am. B 6, 616-621 (1989).

[2] D.A. Keszler, Borates for optical frequency conversion, Curr. Opin. Solid State Mater. Sci. 1, 204-211 (1996).

[3] H.F.H. Yoshida, M. Nakatsuka, M. Yoshimura, T. Sasaki, T. Kamimura, and K. Yoshida, Dependences of laser-induced bulk damage threshold and crack patterns in several nonlinear crystals on irradiation direction, Jpn. J. Appl. Phys. 45, 766 (2006).

[4] E.A. Levchuk, V.V. Novopashin, and A.V.Shestakov, High-quality interference coatings for LBO and $\mathrm{BBO}$ crystals produced by the ion-beam technique, Proc. SPIE 3738, 118-125 (1999).
[5] Z. Deng, H. Gao, L. Xiao, H. He, Z. Fan, and J. Shao, Design and preparation of frequency doubling antireflection coating with different thicknesses of interlayer for LiB3O5 crystal, Chin. Opt. Lett. 5, 60-62 (2007).

[6] T. Tan, J. Shan, W. Wu, Y. Guo, J. Shao, and Z. Fan, Employing $\mathrm{SiO}_{2}$ buffer layer to improve adhesion of the frequency-doubled antireflection coating on LBO, Journal of Wuhan University of Technology - Mater. Sci. Ed. 24, 849-851 (2009).

[7] A. Melninkaitis, T. Tolenis, L. Mažulè, J. Mirauskas, V. Sirutkaitis, B. Mangote, X. Fu, M. Zerrad, L. Gallais, M. Commandré, S. Kičas, and R. Drazdys, Characterization of zirconia and niobia silica mixture coatings produced by ion-beam sputtering, Appl. Opt. 50, C188-C196 (2011).

[8] M. Lappschies, B. Görtz, and D. Ristau, Optical monitoring of rugate filters, Proc. SPIE 5963, 1Z1-1Z9 (2005).

[9] K. Starke, T. Grosz, M. Lappschies, and D. Ristau, Rapid prototyping of optical thin film filters. Proc. SPIE 4094, 83-92 (2000).

[10]K. Starke, L.O. Jensen, M. Jupé, D. Ristau, G. Abromavicius, K. Juskevicius, R. Buzelis, and R. Drazdys, Investigation in oxide mixture coatings with adapted gradient index profiles, Proc. SPIE 7504, 75040B (2009).

[11] ISO 11254-2:2001: Determination of laser-induced damage threshold of optical surfaces - Part 2: S-on-1 test, Lasers and laser-related equipment (2001).

[12]A. Melninkaitis, D. Miksys, T. Balciunas, O. Balachninaite, T. Rakickas, R. Grigonis, and V. Sirutkaitis, Automated test station for laser-induced damage threshold measurements according to ISO 11254-2 standard, Proc. SPIE 6101, 61011J (2006). 


\title{
JONPLUOŠČIO DULKINIMO BŪDU SUFORMUOTŲ SKAIDRINANČIŲ DANGŲ ANT LBO KRISTALŲ SPEKTRINĖS SAVYBĖS IR JŲ ATSPARUMAS LAZERIO SPINDULIUOTEI
}

\author{
G. Abromavičius ${ }^{\text {a, b }}$, R. Buzelis ${ }^{\text {a }}$, R. Drazdys ${ }^{\text {a }}$, K. Juškevičius ${ }^{\text {a }}$, S. Kičas ${ }^{\text {a }}$, T. Tolenis $^{\text {a }}$, J. Mirauskas $^{\text {c }}$, \\ M. Ščiuka ${ }^{c}$, V. Sirutkaitis ${ }^{c}$, A. Melninkaitis ${ }^{c}$ \\ a Valstybinis moksliniu tyrimu institutas Fiziniu ir technologijos mokslu centras, Vilnius, Lietuva \\ ${ }^{\mathrm{b}}$ UAB Optida, Vilnius, Lietuva \\ ' Vilniaus universiteto Lazeriniu tyrimu centras, Vilnius, Lietuva
}

\section{Santrauka}

Netiesiniai $\mathrm{LBO}\left(\mathrm{LiB}_{3} \mathrm{O}_{5}\right)$ kristalai yra plačiai naudojami Nd:YAG, Yb:KGW ir Nd:YLF lazeriuose aukštesnių optinių harmonikų generavimui. Pagrindinis veiksnys, ribojantis jų taikymus - spartus skaidrinančių dangu degradavimas, naudojant $355 \mathrm{~nm}$ bangos ilgio spinduliuotę bei esant dideliems impulsų pasikartojimo dažniams (5-20) kHz. Šio darbo metu buvo sumodeliuotos ir jonpluoščio dulkinimo būdu suformuotos vienbangio su padidintu pralaidumu (AR@355 + HT@532 + 1064) ir tribangio (AR@355 + 532 + 1064) skaidrinimo dangos ant LBO kristalų, naudojant $\mathrm{Al}_{2} \mathrm{O}_{3} / \mathrm{SiO}_{2}$ plonus sluoks-
\end{abstract}

nius bei $\mathrm{ZrO}_{2}-\mathrm{SiO}_{2}$ mišinius. $\mathrm{ZrO}_{2}-\mathrm{SiO}_{2}$ mišinių atveju buvo pasirinktos dangų konstrukcijos su diskrečiu ir tolygiai kintančio lūžio rodiklio profiliais. Geresnei dangos adhezijai su LBO kristalu pasiekti visose dangose buvo naudojamas $\mathrm{SiO}_{2}$ pasluoksnis. Dengtų kristalų optinio pažeidimo slenksčio matavimai buvo atlikti esant $10 \mathrm{~Hz}$ ir $6 \mathrm{kHz}$ impulso pasikartojimo dažniams ir parode, kad daugeliu atvejų atsparesnès dangos buvo suformuotos naudojant $\mathrm{ZrO}_{2}-\mathrm{SiO}_{2}$ mišinius negu UV srities dangoms formuoti tradiciškai naudojamas medžiagas $\mathrm{Al}_{2} \mathrm{O}_{3}$ bei $\mathrm{SiO}_{2}$. 